\title{
Molecular identification of three species of Oncideres (Coleoptera: Cerambycidae) using RAPD markers
}

\author{
GLÁUCIA CORDEIRO ${ }^{1}$, MARINA S. DA CUNHA ${ }^{2}$, CAROLINA R. DA SILVA ${ }^{1}$, \\ ISAAC R. JORGE ${ }^{1}$, JORGE A. DERGAM ${ }^{2}$ and PAULO S.F. FERREIRA ${ }^{1}$
}

\author{
${ }^{1}$ Departamento de Entomologia, Universidade Federal de Viçosa, Av. P.H. Rolfs, s/n, Centro, 36570-900 Viçosa, MG, Brazil \\ ${ }^{2}$ Departamento de Biologia Animal, Universidade Federal de Viçosa, Av. P.H. Rolfs, s/n, Centro, 36570-900 Viçosa, MG, Brazil \\ Manuscript received on March 1, 2018; accepted for publication on September 13, 2018
}

\begin{abstract}
How to cite: CORDEIRO G, CUNHA MS, SILVA CR, JORGE IR, DERGAM JA AND FERREIRA PSF. 2019. Molecular identification of three species of Oncideres (Coleoptera: Cerambycidae) using RAPD markers. An Acad Bras Cienc 91: e20180209. DOI. 10.1590/0001-3765201920180209.
\end{abstract}

\begin{abstract}
Twig girdlers have a short adult life and a long larval stage (up to one year in some species). This fact, together with lack of morphological traits to identify the species from the larval stage, poses obstacles for the taxonomic identification and characterization of the many twig girdlers found in the wild. To solve this matter, Random Amplified Polymorphic DNA (RAPD) molecular markers have been applied to identify some insect species and to determine species boundaries. The aim of this study was to identify three species of Oncideres using the RAPD technique. Adults and larvae of O. saga, O. ocularis and O. ulcerosa were collected in Minas Gerais, Brazil. Two RAPD primers were used (OPA-05 and OPB13), which produced different electrophoretic profiles that were used to construct a UPGMA phenogram. Three groups identified in the analyses accurately separated the three species, based on individuals in two different stages of development (adults and larvae): I: O. saga, II: O. ulcerosa, and III: O. ocularis. Molecular markers, such as RAPD, are valuable tools that help taxonomists in species identification.
\end{abstract}

Key words: Girdled branches, Insect identification, O. ocularis, O. saga, O. ulcerosa, Twig girdler.

\section{INTRODUCTION}

The Cerambycidae belonging to the subfamily Lamiinae are known as "twig girdlers" because of their abilities to girdle branches and main trunks of different species of trees. This behavior is exhibited by females, who deposit their eggs between the shell and the wood of the trees by making incisions with their jaws (Calderón-Cortés et al. 2010, G. Cordeiro, unpublished data). Among twig girdlers, the genus Oncideres is widespread throughout the

Correspondence to: Gláucia Cordeiro

E-mail: glaucordeiro@gmail.com

ORCid: http://orcid.org/0000-0002-9950-5409
Americas, occurring from southern United States to Argentina and in all Brazilian states (Monné 2002). In Brazil, this genus is represented by 41 described species, including Oncideres saga (Dalman, 1823), Oncideres ocularis (Thomson, 1868) and Oncideres ulcerosa (Germar, 1824). Outbreaks of these species are common in Minas Gerais State, and they are considered as pests due to the injuries they cause to their hosts (Monné 2002).

Species identification is usually made by specialists, taxonomic keys, or through morphological comparison with museum specimens, which sometimes leads to description of a new species. Insect identification is commonly 
made using adult specimens, and the absence of morphological traits to identify beetles in their early stages of development is a limiting factor to determine species diversity in the field, specially considering that twig girdlers have a short adult life and a long larval stage, which varies from five months up to one year in some species (Lima 1955). In these conditions, molecular markers are potentially useful as a complementary tool to help in species identification. Among a variety of molecular markers, RAPD (Random Amplified Polymorphic DNA) stands out as an easy, fast, and low-cost technique (Lacerda et al. 2002, Sharma and Singh 2017). This method employs primers with arbitrary sequences, which eliminates the need for prior knowledge of the nucleotide sequences flanking the DNA sequence of interest (Suazo et al. 1998) and it is based on the fact that different species produce different amplification profiles (Milach 1998).

Despite the reproducibility problem of this technique, RAPD markers have become one of the most commonly used techniques to identify genetic differences between populations or species and serve as an addition tool for taxon delimitation (Jain et al. 2010, Bajpai 2016a, Singh et al. 2016, Andrić et al. 2017), even when closely related species are considered (Singh et al. 2011, Bajpai 2016b). This technique has been used in the identification of many insect species: Acromyrmex (Hymenoptera) (Grutzmacher et al. 2007), aphids of the family Aphididae (Hemiptera: Sternorrhyncha) (Helmi and Khafaga 2011), cockroaches (Dictyoptera) (Neekhra et al. 2012), Trichogramma spp. (Hymenoptera) (Ercan et al. 2012), Camponotus rufipes Fabricius, 1775 (Hymenoptera) (Matta et al. 2013), moths of the Erebidae family (Lepidoptera) (Sivasankaran et al. 2013), Cochliomyia hominivorax Coquerel, 1858 (Diptera) (Skoda et al. 2013), and in other insects with agronomic interests (Queiroz et al. 2007, 2016, 2017, Haghighi and Kumar 2017,
Sharma and Singh 2017, Yadav et al. 2017). In the order Coleoptera, Scolytus schevyrewi Semenov, 1902 and Scolytus multistriatus (Marsham, 1802) (Curculionidae) were accurately differentiated with RAPD profiles (Johnson et al. 2008), as well as ten scarab beetle species (Scarabaeidae) (Zahoor et al. 2013) and three sibling species of Trogoderma dejean (Dermestidae) (Yulin et al. 1999). Yulin et al. (1998) used RAPD to separate three species of Monochamus (Cerambycidae) using adults and larvae individuals. Therefore, the aim of this study was to identify three species of Oncideres (O. saga, O. ocularis and O. ulcerosa) using RAPD markers on adults and larvae specimens.

\section{MATERIALS AND METHODS}

\section{SAMPLE COLLECTION}

Branches of Acacia mangium Willd., Ficus benjamina L. and Mimosa caesalpiniifolia Benth girdled by $O$. saga, O. ulcerosa, and O. ocularis, respectively, were collected in Viçosa, Minas

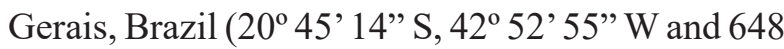
$\mathrm{m})$, in January and February 2012. The branches of A. mangium $(\mathrm{n}=3)$ had a length and diameter of $4.35 \pm 1.03 \mathrm{~m}$ and $4.11 \pm 0.41 \mathrm{~cm}$, respectively, and $88 \pm 20.46$ posture incisions. The branches of F. benjamina $(\mathrm{n}=10)$ had a length and diameter of $1.60 \pm 0.14 \mathrm{~m}$ and $0.94 \pm 0.04 \mathrm{~cm}$, respectively, and $16 \pm 2$ posture incisions. The branches of $M$. caesalpiniifolia $(\mathrm{n}=10)$ had a length and diameter of $1.59 \pm 0.07 \mathrm{~m}$ and $1.57 \pm 0.06 \mathrm{~cm}$, respectively, and $13 \pm 1$ posture incisions. The branches were sampled in areas of occurrence of only one Oncideres spp., as they girgle different tree species - with reference to the 2011 outbreak - to ensure the presence of emerging adults as well as larvae specimens. After the emergence of the adults, the specimens were sent to the taxonomist Prof. Dr. Miguel Angel Monné Barrios for identification, in the Museu Nacional da Universidade Federal do Rio de Janeiro, Rio de Janeiro, Brazil. 
The twig girdlers were stored in sealed buckets (65 L) and kept under controlled conditions (temperature: 15 to $30{ }^{\circ} \mathrm{C}$; relative humidity: 52 87\%; and a 12-hour photoperiod; and moistened periodically). The molecular analysis was performed using individuals in two different stages of development: larvae (three individuals of each species) and adults (O. saga: 3 specimens, O. ocularis: 2 specimens, and O. ulcerosa: 1 specimen).

\section{MOLECULAR ANALYSIS WITH RAPD}

DNA extraction was performed according to Boyce et al. (1989), using paws from adults and abdomens from larvae. Two RAPD primers were used in the analyses: OPA-05 (5' - TTCCCCCGCT - 3') and OPB-13 (5' - AGGGGTCTTG - 3') (OPERON Technologies), according to the manufacturer's instructions. Polymerase chain reactions (PCR) were carried out in $20 \mu \mathrm{L}$ volume [ $13.8 \mu \mathrm{L} \mathrm{H}_{2} \mathrm{O}, 2.0$ $\mu \mathrm{L} 10 \mathrm{x}$ buffer (200 mM Tris- $\mathrm{HCl} \mathrm{pH} 8.4,500 \mathrm{mM}$ $\mathrm{KCl}), 0.8 \mu \mathrm{L}$ of $\mathrm{MgCl}_{2}(100 \mathrm{mM}), 0.2 \mu \mathrm{L}$ dNTPs (20 mM), $2.0 \mu \mathrm{L}$ of each primer $(10 \mu \mathrm{M}), 0.2 \mu \mathrm{L}$ of Taq polymerase (Phoneutria) (2.5 U. $\mu \mathrm{L}^{-1}$ ), and $1 \mu \mathrm{L}$ of DNA (100 ng. $\left.\left.\mu \mathrm{L}^{-1}\right)\right]$. The PCR conditions were: 45 cycles of 15 seconds at $95{ }^{\circ} \mathrm{C}, 30$ seconds at $35^{\circ} \mathrm{C}$, and one minute at $72{ }^{\circ} \mathrm{C}$, with 60 seconds of initial denaturation at $95{ }^{\circ} \mathrm{C}$ and seven minutes of final extension at $72{ }^{\circ} \mathrm{C}$. The PCR products were electrophoresed at $70 \mathrm{~V}$ in $6.0 \%$ polyacrylamide gel for approximately three hours, using $0.5 \mathrm{X}$ Tris Boric acid (TBE) buffer, along with a DNA molecular size marker, DNA Ladder 1 kb (Sigma) (Hiss et al. 1994).

\section{DATA ANALYSIS}

Amplification profiles were compared with each other and with the molecular size marker. Bands of DNA fragments were scored as present (1) or absent (0). The ambiguous bands that could not be clearly discriminated were not included in further analysis. The binary matrices were processed with the FORTRAN RAPDPLOT program to determine the molecular similarity (Kambhampati et al. 1992, Black 1993). An unweighted pair group method with arithmetic averages (UPGMA) was calculated using the PHYLIP 3.5C software package NEIGHBOR option (Felsenstein 1993), and a phenogram was drawn using the DRAWGRAM option of the same package.

\section{RESULTS}

Based on the established DNA extraction methodology, it was possible to obtain RAPD electrophoretic profiles from different Oncideres species.

The OPA-05 (Figure 1a) and OPB-13 (Figure 1b) RAPD markers showed different electrophoretic profiles among species, with bands varying from 2.0 to $0.5 \mathrm{~kb}$. The OPA-05 marker had the largest number of polymorphic fragments (Table I) and it may be considered more suitable for the differentiation of twig girdler beetles.

The data obtained from the analysis of the electrophoretic profiles were used to estimate the genetic similarity between individuals and the variation between the studied species. The phenogram generated from the UPGMA method showed the presence of three groups: Group I was formed by individuals of $O$. saga, group II by individuals of $O$. ulcerosa, and group III by individuals of $O$. ocularis (Figure 2).

\section{DISCUSSION}

This is the first study to employ a molecular tool to help identify Oncideres species in different stages of development. According to Jain et al. (2010), RAPD markers generate consistent results, produced in optimized conditions, and are useful for phylogenetic inferences and taxonomic classification. This molecular marker has an advantage of the possibility of using a different set 

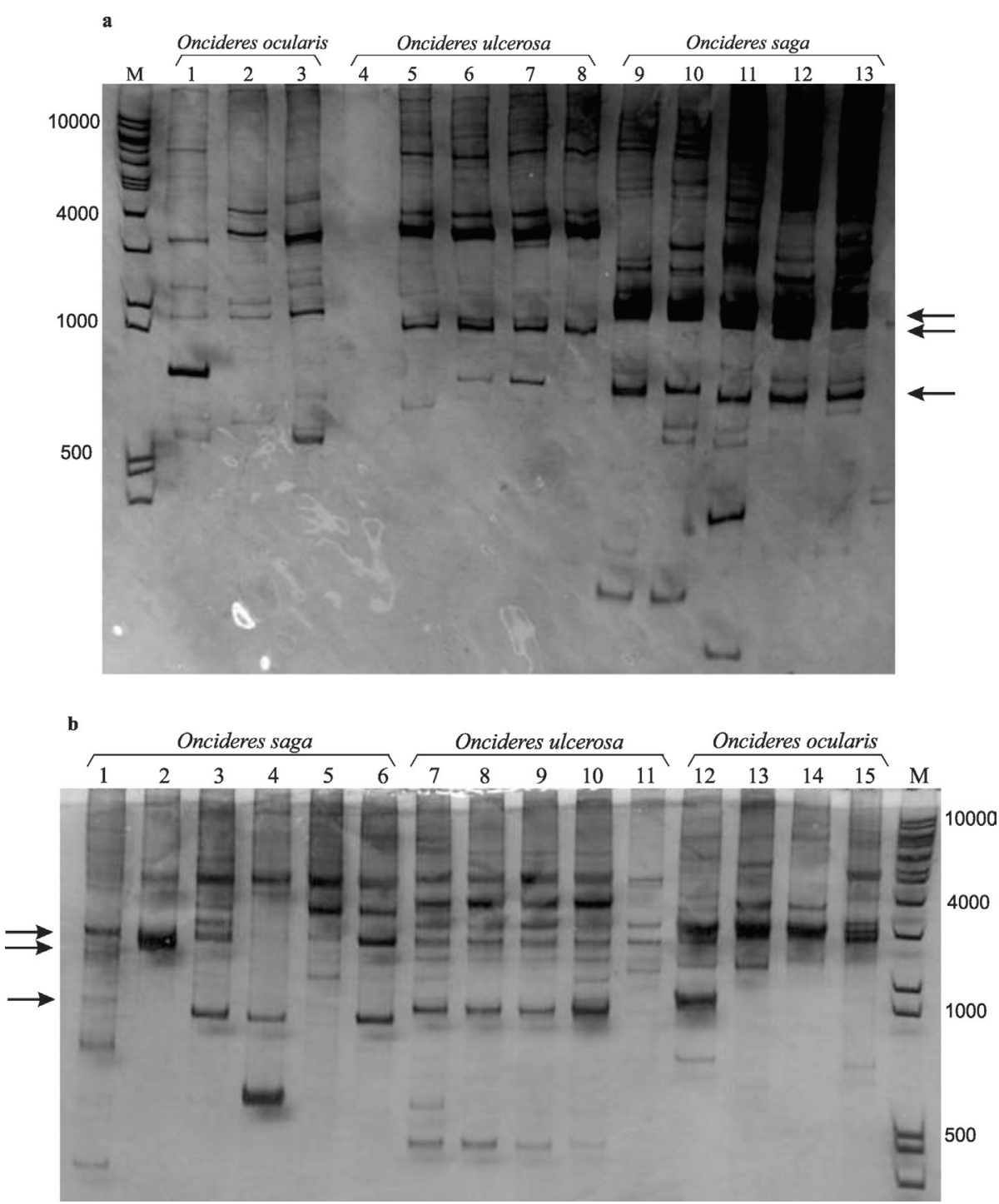

Figure 1 - Electrophoretic profiles obtained with two RAPD primers in the three species of Oncideres. (a) OPA-05 primer: 1 and $2=$ Oncideres ocularis larvae; $3=O$. ocularis adult; 4,5 , and $6=O$. ulcerosa larvae; 7 and $8=O$. ulceros $a$ adults; 9 and $10=O$. saga larvae; 11 , 12 , and $13=O$. saga adults. (b) OPB-13 primer: 1,2 , and $3=O$. saga adults; 4,5 , and $6=O$. saga larvae; 7 and $8=O$. ulcerosa adults; 9,10 , and $11=O$. ulcerosa larvae; $12=O$. ocularis adult; 13,14 , and $15=O$. ocularis larvae. $\mathrm{M}$ indicates the molecular marker DNA Ladder $1 \mathrm{~Kb}$ (Sigma). Arrows indicate specific bands of interest.

of primers and choosing the best for each analysis as different sets of primers often produce different banding patterns that can be used in a variety of studies (Yulin et al. 1998, Grutzmacher et al. 2007, Johnson et al. 2008, Zahoor et al. 2013, CoelhoBortolo et al. 2016, Preet and Gupta 2017). Therefore, these markers have several entomological applications, for example, in forensic entomology, breeding programs, taxonomic identification of pests of agronomic interests, detection of genetic variation among populations, as well as, in the identification of closely related species (Grzywacz et al. 2012, Ercan et al. 2012, Sivasankaran et al. 2013, Matta et al. 2013, Sunitha et al. 2015, Singh et al. 2016, Haghighi and Kumar 2017, Queiroz et al. 2017, Sharma and Singh 2017). 
TABLE I

Polymorphism observed among Oncideres species according to the primer used in the RAPD reaction.

\begin{tabular}{|c|c|c|c|c|}
\hline Primer & Species & $\begin{array}{l}\text { Number of amplified } \\
\text { fragments }\end{array}$ & $\begin{array}{l}\text { Number of polymorphic } \\
\text { fragments }\end{array}$ & $\begin{array}{c}\text { Percentage of } \\
\text { polymorphism } \\
(\%)\end{array}$ \\
\hline \multirow[t]{3}{*}{ OPA-05 } & Oncideres saga & 27 & 24 & 88.9 \\
\hline & Oncideres ulcerosa & 15 & 15 & 100 \\
\hline & Oncideres ocularis & 15 & 15 & 100 \\
\hline \multirow[t]{3}{*}{ OPB-13 } & Oncideres saga & 23 & 22 & 95.7 \\
\hline & Oncideres ulcerosa & 15 & 11 & 73.3 \\
\hline & Oncideres ocularis & 16 & 2 & 12.5 \\
\hline
\end{tabular}

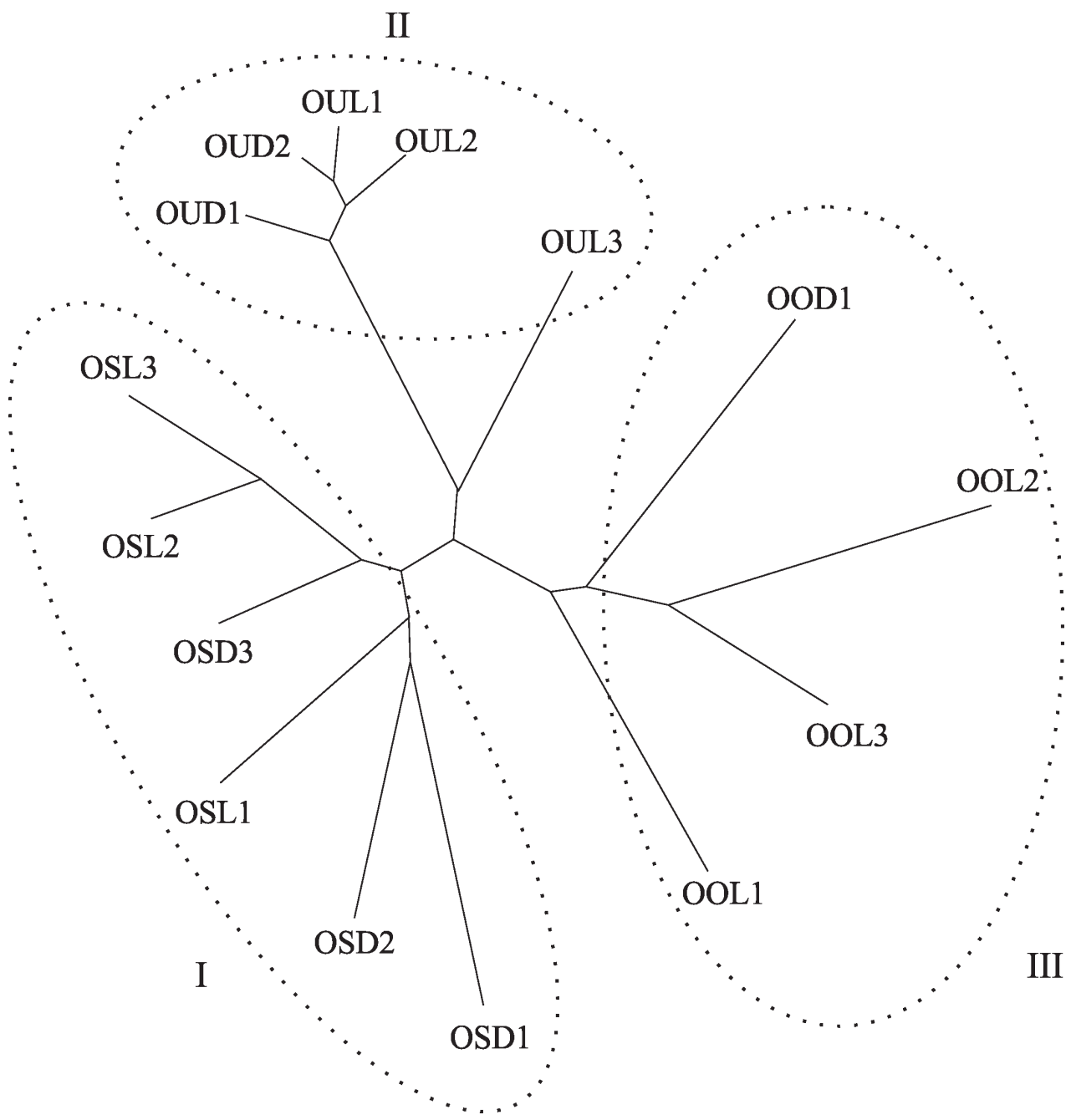

Figure 2 - UPGMA phenogram in the three species of Oncideres. Group I: OSD = Oncideres saga adults and $\mathrm{OSL}=O$. sag $a$ larvae; Group II: OUD $=$ Oncideres ulceros $a$ adults and OUL $=O$. ulcerosa larvae; Group III: $\mathrm{OOD}=$ Oncideres ocularis adults and $\mathrm{OOL}=O$. ocularis larvae. 
With regard to species identification, the analysis of electrophoretic profiles has been used in other groups of insects, with satisfactory results (Yulin et al. 1998, 1999, Johnson et al. 2008, Sivasankaran et al. 2013, Zahoor et al. 2013, Bajpai 2016a, b). Queiroz et al. (2005) suggested that RAPD markers could be used for the development of specific primers for Coleoptera species. Moreover, by using one or two RAPD markers, scarab beetles (Coleoptera) could be accurately identified (Zahoor et al. 2013).

The Oncideres species analyzed in the present study (O. saga, O. ocularis and O. ulcerosa) have a long larval stage that varies from five to seven months (C.L. Coutinho, unpublished data, G. Cordeiro, unpublished data), characterizing a major problem in taxonomic identification, because in the wild, they look identical during this developmental stage. The use of the RAPD molecular markers to identify species with identical morphology at early stages of development have been successfully reported, as in flesh flies (Diptera) (Bajpai 2016a), enchancing the power of this technique to the taxonomy field. Yadav et al. (2017) argue that the results of the genetic variability of important economic pests provide useful information that could be used to design suitable strategies to control the spreading of these pests. It may also be useful in determining chemical control methods in relation to a specific host crop and in the management of resistance to insecticides (Coelho-Bortolo et al. 2016, Queiroz et al. 2017, Yadav et al. 2017).

The RAPD identification of these three Oncideres species was confirmed by the taxonomist based on morphological traits of the adults, with the advantage of allowing identification of the individuals in the early stages of development, correctly clustering larvae with adults in their respective species. This is the first study using molecular markers as an auxiliar tool to help identify twig girdles species in Brazil. Additional identification methods for these insects that are considered pests are important to monitor the outbreaks they may cause, damaging tree species in the forest, besides supporting phylogenetic studies.

In conclusion, we can state that the RAPD marker has been efficient in discriminating the Oncideres species and we indicate this technique as an auxiliary tool to identify different species in early stages of development.

\section{ACKNOWLEDGMENTS}

The authors thank the Conselho Nacional de Desenvolvimento Científico e Tecnológico (CNPq), Coordenação de Aperfeiçoamento de Pessoal de Nível Superior (CAPES) and Fundação de Amparo à Pesquisa do Estado de Minas Gerais (FAPEMIG) for financial support.

\section{AUTHOR CONTRIBUTIONS}

Gláucia Cordeiro and Paulo Sérgio Fiuza Ferreira conceived this research and designed the experiments. Gláucia Cordeiro, Marina Souza da Cunha and Jorge Abdala Dergam participated in the design and interpretation of the data. Gláucia Cordeiro, Marina Souza da Cunha, Carolina Rocha da Silva and Isaac Reis Jorge performed experiments and analysis.Gláucia Cordeiro, Marina Souza da Cunha, Carolina Rocha da Silva, Isaac Reis Jorge, Paulo Sérgio Fiuza Ferreira wrote the paper and participated in the revisions of it. All authors read and approved the final manuscript.

\section{REFERENCES}

ANDRIĆ A, TUBIĆ NK, DAN M, VUJIĆ A AND VIDAKOVIĆ DO. 2017. Assessment of genetic diversity within the Merodon ruficornis species group (Diptera: Syrphidae) by RAPD analysis. Arch of Biol Sci 69(3): 553-560.

BAJPAI N. 2016a. Random amplified polymorphic DNA based characterization of flesh flies. J Entomol Zool Stud 4(5): 857-859.

BAJPAI N. 2016b. RAPD-PCR based characterization of sarcophagid flies. J Zool Stud 3(5): 20-23. 
BLACK WC. 1993. PCR with arbitrary primers: approach with care. Insect Mol Biol 2: 1-6.

BOYCE TM, ZWICK ME AND AQUADRO CF. 1989. Mitochondrial DNA in the bark weevils: size, structure and heteroplasmy. Genetics 123: 825-836.

CALDERÓN-CORTÉS N, WATANABE H, CANOCAMACHO H, ZAVALA-PÁRAMO G AND QUESADA M. 2010. cDNA cloning, homology modelling and evolutionary insights into novel endogenous cellulases of the borer beetle Oncideres albomarginata chamela (Cerambycidae). Insect Mol Biol 19(3): 323-336.

COELHO-BORTOLO T, MANGOLIN CA AND LAPENTA AS. 2016. Genetic variability in the natural populations of Lasioderma serricorne (F.) (Coleoptera: Anobiidae), detected by RAPD markers and by esterase isozymes. Bull Entomol Res 106(1): 47-53.

ERCAN FS, ÖZTEMİ S, ÖZCAN S AND TUNÇBİLEK AŞ. 2012. Detection of genetic polymorphism by RAPD-PCR in two Trichogramma (Hymenoptera: Trichogrammatidae) species in Turkey. Turk Entomol Derg 36(2): 177-182.

FELSENSTEIN J. 1993. PHYLIP (Phylogeny Inference Package) v 3.5c. Department of Genetics, University of Seattle, WA.

GRUTZMACHER DD, LOECK AE, OLIVEIRA AC, ZIMMER PD AND MALONE G. 2007. Variabilidade genética interespecífica em formigas cortadeiras do gênero Acromyrmex que ocorrem no Estado do Rio Grande do Sul. Cienc Rural 37(4): 921-927.

GRZYWACZ B, WARCHALOWSKA-OELIWAE, BANACH Z AND PYZA E. 2012. Genetic variability and changes of elemental concentrations in cells of Tetrix tenuicornis (Orthoptera: Tetrigidae) from polluted and unpolluted áreas. Folia Biol (Krakow) 60(1-2): 17-25.

HAGHIGHI MT AND KUMAR TSJ. 2017 Genetic divergence and allelic-specificity in relation to expression of voltinism in silkworm using ISSR and RAPD fingerprinting. Russ J Genet 53(2): 267-274.

HELMI A AND KHAFAGA AF. 2011. Molecular fingerprinting of certain cereal aphids in Egypt (Hemiptera: Sternorrhyncha: Aphididae) using RAPD and ISSRs markers. J Entomol 8(4): 327-340.

HISS RH, NORRIS DE, DIETRICH CR, WHITCOMB RF, WEST DF, BOSIO CF, KAMBHAMPATI S, PEISMAN J, ANTOLIN MF AND BLACK WC. 1994. Molecular taxonomy using single strand conformation polymorphism (SSCP) analysis of mitochondrial DNA genes. Insect Mol Biol 2: 171-182.

JAIN SK, NEEKHRA B, PANDEY D AND JAIN K. 2010. RAPD marker system in insect study: a review. Indian $\mathrm{J}$ Biotechnol 9: 7-12.

JOHNSON PL, HAYES JL, RINEH J, SHEPPARD WS AND SMITH SE. 2008. Characterization of two non-native invasive bark beetles, Scolytus schevyrewi and Scolytus multistriatus (Coleoptera: Curculionidae: Scolytinae). Can Entomol 140(5): 527-538.

KAMBHAMPATI S, BLACK WC AND RAI KS. 1992. Random amplified polymorphic DNA of mosquito species and populations (Diptera: Culicidae): techniques, statistical analysis, and applications. J Med Entomol 29(6): 939-945.

LACERDA DR, ACEDO MDP, LEMOS FILHO JP AND LOVATO MB. 2002. A técnica de RAPD: uma ferramenta molecular em estudos de conservação de plantas. Lundiana 3(2): 87-92.

LIMA AC. 1955. Insetos do Brasil: Coleópteros. Rio de Janeiro: Escola Nacional de Agronomia, $9^{\circ}$ Tomo, $3^{\underline{a}}$ Parte, 289 p. (Série Didática, 11).

MATTA SLSF, MORINI MSC AND HILSDORF AWS. 2013. Genetic relationship among Camponotus rufipes Fabricius (Hymenoptera: Formicidae) nests by RAPD molecular markers. Acta Sci Biol Sci 35(1): 89-92.

MILACH SCK. 1998. Principais tipos de marcadores moleculares e suas características. In: Milach SCK. Marcadores moleculares em plantas. Porto Alegre: UFRGS, p. 17-28.

MONNÉ MA. 2002. Catalogue on the Neotropical Cerambycidae (Coleoptera) with known host plant. PART IV: Subfamily Lamiinae, tribes Batocerini to Xenofreini. Publ Avulsas Mus Nac 94: 92 p.

NEEKHRA B, PANDEY D AND JAIN SK. 2012. RAPD-PCR based marker approach for the genetic differentiation of two species of cockroach (Order: Dictyoptera). J Life Sci 6: 1328-1333.

PREET S AND GUPTA S. 2017. Genetic diversity studies on Culex quinquefasciatus from diverse larval habitats using RAPD-PCR marker. Int J Mosq Res 4(2): 93-98.

QUEIROZ PR, LIMA LH, SUJII ER AND MONNERAT RG. 2017. Description of the molecular profiles of Bemisia tabaci (Hemiptera: Aleyrodidae) in different crops and locations in Brazil. J Entomol Nematol 9(5): 36-45.

QUEIROZ PR, MARTINS ES, LIMALHC AND MONNERAT RG. 2005. Caracterização molecular de uma população de Anthonomous grandis (Coleoptera: Curculionidade) utilizando marcadores moleculares RAPD. Brasília: Embrapa Recursos Genéticos e Biotecnologia, 19 p. (Embrapa Recursos Genéticos e Biotecnologia. Boletim de Pesquisa e Desenvolvimento, 90).

QUEIROZ PR, MARTINS ES, PRAÇA LB, LIMA LHC AND MONNERAT RG. 2007. Identificação de populações de insetos-praga utilizando marcadores moleculares RAPD. Brasília: Embrapa Recursos Genéticos e Biotecnologia, (Embrapa Recursos Genéticos e Biotecnologia. Boletim de Pesquisa e Desenvolvimento, 167).

QUEIROZ PR, RAMIRO CA, MARTINS ES, SOBERÓN M, BRAVO A AND MONNERAT RG. 2016. Mitochondrial markers to distinguish Spodoptera frugiperda populations 
associated with corn and cotton crops. Pesq Agropec Bras 51(5): 692-696.

SHARMA M AND SINGH D. 2017. Utility of Random Amplified Polymorphic DNA (RAPD) In Forensic Entomology. Int J Sci Res Sci Technol 3: 56-58.

SINGH R, BAJPAI N AND TEWARI RR . 2011. Genetic characterization of Bactrocera (DACUS) flies (Diptera: Tephritidae) based on RAPD-PCR. Int J Pharma Bio Sci 2: 498-503.

SINGH VK, JOSHI PC, BISHT SPS, KUMAR S, NATH P, AWASTHI S AND MANSOTRA DK. 2016. Molecular characterization of butterflies and its significances in taxonomy. J Entomol Zool Stud 4(2): 545-547.

SIVASANKARAN K, PARANDHAMAN D, RAMAKRISHNAN M AND IGNACIMUTHU S. 2013. Molecular studies of family Erebidae moths (Lepidoptera: Noctuoidea) using RAPD-PCR technique. Elixir Appl Zoology 62: 17634-17639.

SKODA S, FIGAROLA JL, PORNKULWAT S AND FOSTER JE. 2013. Inter- and intraspecific identification of the screwworm, Cochliomyia hominivorax, using random amplified polymorphic DNA-polymerase chain reaction. J Insect Sci 13: 1-15.

SUAZO A, MCTIERNAN R AND HALL HG. 1998. Differences between African and European honey bees (Apis mellifera L.) in Random Amplified Polymorphic DNA (RAPD). J Hered 9: 32-36.
SUNITHA V, SINGH TVK, RAMESH BABU V AND SATYANARAYANA J. 2015. Genetic diversity assessment using RAPD primers in insecticide resistant populations of diamondback moth Plutella xylostella (Linn.). J Appl Nat Sci 7(1): 219-225.

YADAV SKU, SINGH J, PADMANABAN B AND KUMAR LS. 2017. Genetic variability in Indian populations of banana corm weevil [Cosmopolites sordidus (Coleoptera: Curculionidae)] assessed by RAPDs and AFLPs. Int J Trop Insect Sci 37(3): 149-162.

YULIN A, CAIHUA D, HONGBING Z AND GUOYAO J. 1998. RAPD assessment of three sibling species of Monochamus Guer. Coleoptera: Cerambycidae. Int J Trop Insect Sci 224(78): 35-38.

YULIN A, CAIHUA D, HONGBING Z AND GUOYAO J. 1999. RAPD assessment of three sibling species of Trogoderma dejean (Coleoptera: Dermestidae). In: Jin Z, Liang Q, Liang Y, Tan X and Guan L (Eds), Proceedings of the $7^{\text {th }}$ International Working Conference on StoredProduct Protection, Beijing, China. Chengdu, China, p. 1755-1757.

ZAHOOR MK, SUHAIL A, ZAHOOR S, IQBAL A AND AWAN FS. 2013. Molecular characterization of scarab beetles (Scarabaeidae: Coleoptera) using RAPD markers. Pak J Life Soc Sci 11(3): 238-243. 